\title{
Mechanical support of superior cavopulmonary (Glenn) physiology to heart transplantation
}

\author{
Edo K. S. Bedzra, MD, MBA, Aliessa Barnes, MD, Brian Birnbaum, MD, and James D. St. Louis, MD, \\ Kansas City, Mo
}

\footnotetext{
From the Children's Mercy Hospital, Ward Family Heart Center, Kansas City, Mo. Disclosures: The authors reported no conflicts of interest.

The Journal policy requires editors and reviewers to disclose conflicts of interest and to decline handling or reviewing manuscripts for which they may have a conflict of interest. The editors and reviewers of this article have no conflicts of interest.

Received for publication Oct 15, 2020; accepted for publication Oct 19, 2020; available ahead of print Oct 22, 2020.

Address for reprints: Edo K. S. Bedzra, MD, MBA, Children's Mercy Hospital, Ward Family Heart Center, 2401 Gilham Rd, Kansas City, MO 64108 (E-mail: ekbedzra@cmh.edu).

JTCVS Techniques 2021;6:144-6

2666-2507

Copyright $@ 2020$ The Authors. Published by Elsevier Inc. on behalf of The American Association for Thoracic Surgery. This is an open access article under the CC BY-NC-ND license (http://creativecommons.org/licenses/bync-nd/4.0/).

https://doi.org/10.1016/j.xjtc.2020.10.016
}

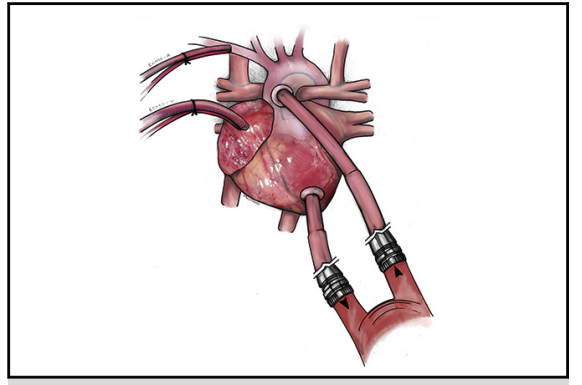

Parallel ECMO and Berlin VAD mechanical support of the bidirectional Glenn patient.

\section{CENTRAL MESSAGE \\ Long-term VAD support of Glenn physiology is feasible with ECMO for pulmonary support instituted in parallel over short intervals.}

See Commentaries on pages 147 and 149
Experience in mechanical circulatory support of the single ventricle has grown as device design and applications have improved. ${ }^{1}$ However, the appetite for assist of the second-stage bidirectional cavopulmonary connection continues to lag because it is fraught with challenges, including respiratory failure, leading to inferior outcomes. ${ }^{2}$ We report the successful bridge to transplantation of a child with failing superior cavopulmonary circulation using the EXCOR pediatric ventricular assist device (VAD), Berlin VAD (Berlin Heart, Berlin, Germany), and interval parallel venoarterial (VA) extracorporeal membrane oxygenation (ECMO) (Video 1).

\section{CASE REPORT}

This was a patient with heterotaxy and transitional atrioventricular septal defect, double-outlet right ventricle with subaortic ventricular septal defect, subaortic obstruction from atrioventricular valve tissue, and moderate-to-severe pulmonary stenosis. At 9 months and $7.7 \mathrm{~kg}$, he presented for a Damus-Kaye-Stansel procedure and bilateral bidirectional Glenn. Preoperative workup showed a $9 \mathrm{~mm} \mathrm{Hg}$ left atrial pressure, $10 \mathrm{~mm} \mathrm{Hg}$ transpulmonary gradient, and 2 Wood units pulmonary vascular resistance and a moderately dilated left ventricle with mild global hypokinesis. He was thus started on milrinone. We expected improved ventricular function after volume unloading. However, he could not be weaned from bypass postoperatively. VA-ECMO was instituted via the innominate artery and right atrial cannulae. This provided sufficient decompression of his Glenn circuit with pressures 12 to $16 \mathrm{~mm}$ $\mathrm{Hg}$, no cerebral edema, and near-infrared spectroscopy values of 50 s to $60 \mathrm{~s}$.

On postoperative day 9, the patient was listed for heart transplantation. After 17 days of support, an oxygenator clamping trial showed acceptable oxygenation. A decision was thus made to proceed to long-term VAD placement. A 6-mm Berlin arterial cannula was placed to the DamusKaye-Stansel and an inflow cannula implanted into the left ventricular apex. These were connected to a 25-cc Berlin pump. With no pulmonary pathology, we did not splice an oxygenator into the VAD circuit. However, the patient failed separation from cardiopulmonary bypass due to poor oxygenation. Therefore, ECMO was reinstituted in parallel with the VAD through the existing right atrial and innominate arterial cannulation (Figure 1). We provided enough ECMO flow for effective oxygenation at $50 \mathrm{~mL} / \mathrm{kg} / \mathrm{min}$ while operating the Berlin VAD at 60 beats per minute and $30 \%$ systole to enable adequate filling. This allowed excellent Glenn circuit decompression. After 5 days, ECMO was weaned with acceptable oxygen saturations. 


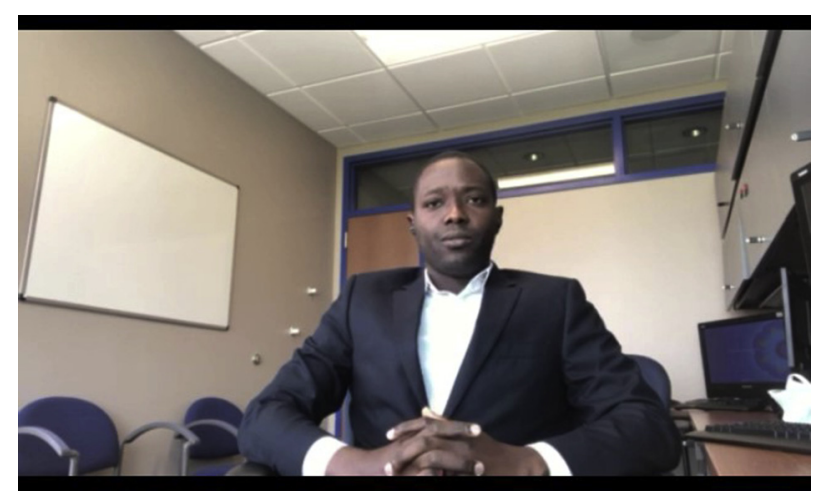

VIDEO 1. Dr Bedzra discusses the case of a 9-month-old patient with a failing Glenn circuit who underwent support with the EXCOR Pediatric ventricular assist device and required a short interval of extracorporeal membrane oxygenation support for poor oxygenation. The patient was successfully bridged to heart transplantation after 369 days on the assist device, demonstrating that durable support of the Glenn circulation can be achieved with short ECMO runs as needed in the immediate perioperative period. Video available at: https://www.jtcvs.org/article/S2666-2507(20) 30590-3/fulltext.

The patient was thus transitioned to Berlin Heart support of his systemic ventricle with settings optimized for ventricular and Glenn decompression. He initially bled on heparin anticoagulation but had no recurrence after transition to bivalirudin, aspirin, and dipyridamole. In addition, he had an initial high fibrin burden necessitating a Berlin pump exchange in the fourth week of support. He had no other thrombotic events or strokes. He did undergo antibiotic treatment for a Pseudomonal cannula site infection but remained listed for transplantation, with calculated panel reactive antibodies of $<10 \%$. The patient otherwise thrived

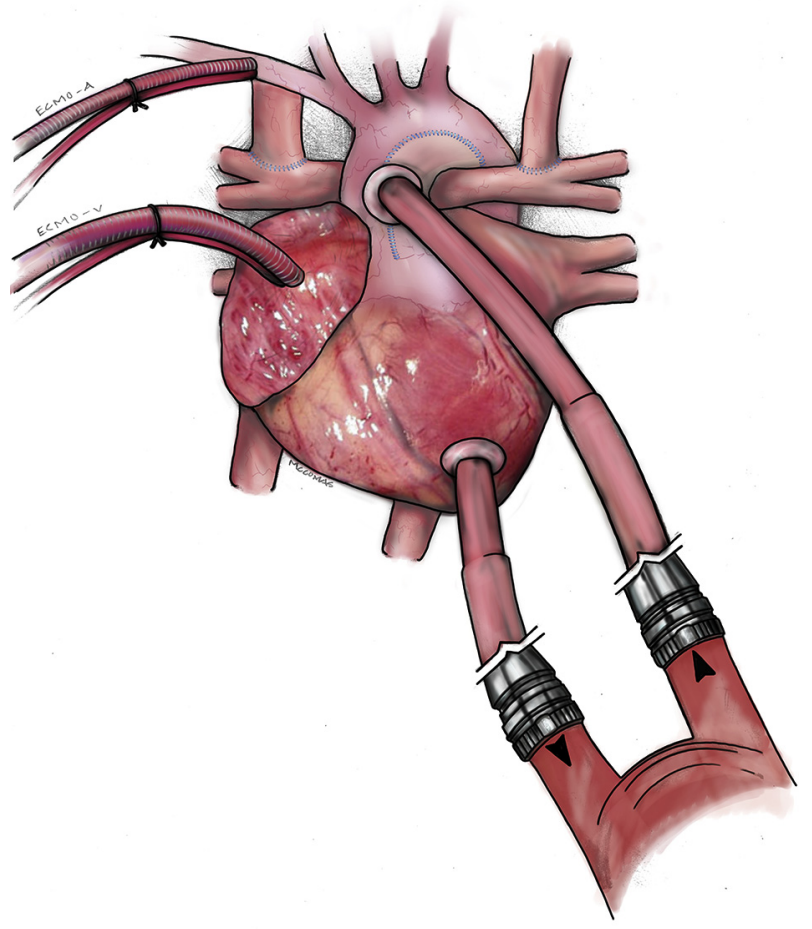

FIGURE 1. Parallel support of the patient with failing bidirectional Glenn physiology showing EXCOR Pediatric ventricular assist device with cannulae in the Damus-Kaye-Stansel connection and left ventricle (lower right) and extracorporeal membrane oxygenation with cannulae in the innominate artery (ECMO-A) and right atrium (ECMO-V).

on support. He was maintained on milrinone for the duration of support and had no significant hypertension despite requiring high flows. Device changes were largely in

TABLE 1. Changes in patient physiology on mechanical circulatory support

\begin{tabular}{|c|c|c|c|c|c|}
\hline $\begin{array}{c}\text { Days after Berlin } \\
\text { heart implant }\end{array}$ & $\begin{array}{c}\text { Patient } \\
\text { weight, kg }\end{array}$ & $\begin{array}{c}\text { Device } \\
\text { rate }\end{array}$ & $\begin{array}{c}\text { Blood pressure, } \\
\text { mm Hg }\end{array}$ & $\begin{array}{c}\text { Oxygen saturation } \\
\text { (after device changes) }\end{array}$ & Other information \\
\hline 0 & 8.7 & 60 & $92 / 55$ & $84 \%$ & $\begin{array}{l}\text { Implantation, remained on } \\
\text { ECMO }\end{array}$ \\
\hline 5 & 8.8 & 70 & $84 / 47$ & $70 \%$ & $\begin{array}{l}\text { Chest washout, ECMO } \\
\text { decannulation }\end{array}$ \\
\hline 45 & 10.5 & 80 & $94 / 52$ & $68 \%(80 \%)$ & $\begin{array}{l}\text { Catheterization: minimal } \\
\text { collaterals, Glenn pressure } \\
22 \mathrm{~mm} \mathrm{Hg} \text {, left ventricular end } \\
\text { diastolic pressure } 16 \mathrm{~mm} \mathrm{Hg}\end{array}$ \\
\hline 58 & 9.6 & 90 & $82 / 48$ & $75 \%(80 \%)$ & $\begin{array}{l}\text { Increased liver function tests and } \\
\text { diuretic need. Percent systole } \\
\text { changed from } 40 \% \text { to } 35 \%\end{array}$ \\
\hline 182 & 10.9 & 90 & $100 / 56$ & $73 \%$ & Increased tachypnea \\
\hline 249 & 12.5 & 90 & $101 / 58$ & $76 \%$ & \\
\hline 350 & 14.1 & 90 & $113 / 73$ & $79 \%$ & $\begin{array}{l}\text { Immediately before } \\
\text { transplantation }\end{array}$ \\
\hline
\end{tabular}

Blood pressure was relatively stable on milrinone. ECMO, Extracorporeal membrane oxygenation. 
response to desaturation and weight gain (Table 1). He required ventricular support for 367 days, after which he underwent heart transplantation. He is thriving 2 years posttransplant with no neurologic issues and only 1 rejection episode. Informed consent was waived per institutional review board policies.

\section{DISCUSSION}

Long-term support of the bidirectional cavopulmonary Glenn circulation is challenging. There are isolated case reports of successful bridge of the Glenn circulation to transplantation, and simulations suggest successful augmentation of cardiac output. ${ }^{3,4}$ However, this comes with major risks of morbidity and mortality during support, including respiratory failure, pump thrombosis, and strokes. ${ }^{2}$ Some authors have reverted to a shunted or converted to a Fontan palliation before VAD implantation to improve oxygenation. These have significant downsides as the shunted physiology is an unstable one while too-early conversion can result in elevated Fontan circuit pressures and low cardiac output. ${ }^{2,5}$ In an early Glenn failure like we have presented, then, support with temporary VA-ECMO in addition to the durable VAD can be valuable. Particularly through the initial postoperative period when the physiology is most tenuous, and the pulmonary vascular bed perhaps most reactive, this dual support can facilitate successful long-term support of the Glenn physiology. This of course comes with the additional attendant risks of ECMO and requires a team well versed in the management of this parallel circulation. Even so, our case suggests 2 important findings: (1) successful long-term VAD support is feasible in patients with Glenn physiology, and (2) ECMO in parallel can be instituted over short intervals to provide pulmonary support.

\section{References}

1. Poh CL, Chiletti R, Zannino D, Brizard C, Konstantinov IE, Horton S, et al. Ventricular assist device support in patients with single ventricles: the Melbourne experience. Interact Cardiovasc Thorac Surg. 2017;25:310-6.

2. Maeda K, Nasirov T, Yarlagadda V, Hollander SA, Navaratnam M, Rosenthal DN, et al. Evolution of single ventricular assist device support for the failing bidirectional Glenn patient. Ann Thorac Surg. 2020;110:1659-66.

3. Mongé MC, Kulat BT, Eltayeb O, Zingle NR, Moss ST, Gossett JG, et al. Successful bridge-to-transplant of functionally univentricular patients with a modified continuous-flow ventricular assist device. Artif Organs. 2017;41:25-31.

4. Molfetta AD, Amodeo A, Gagliardi MG, Trivella MG, Fresiello L, Filippelli S, et al. Hemodynamic effects of ventricular assist device implantation on Norwood, Glenn, and Fontan circulation: a simulation study. Artif Organs. 2016;40:34-42.

5. Adachi I, Williams E, Jeewa A, Elias B, McKenzie ED. Mechanically assisted Fontan completion: a new approach for the failing Glenn circulation due to isolated ventricular dysfunction. J Heart Lung Transplant. 2016;35:1380-1. 